\title{
An examination of the relationships between customer relationship management quality, service quality, customer satisfaction and customer loyalty: The case of five star hotels
}

\author{
Susiana Mokhtar \\ School of Economics Makassar (STIEM Bongaya) Indonesia \\ Abd. Mansyur Mus \\ School of Economics Makassar (STIEM Bongaya) Indonesia \\ Herman Sjahruddin \\ School of Economics Makassar (STIEM Bongaya) Indonesia
}

\begin{abstract}
Customer's loyalty seems to have received a lot of attention from scholars. This research began by describing customer relationship management (CRM) quality and service quality. The meditational model that links CRM quality and service quality with customer loyalty through customer satisfaction is proposed. Appropriate steps are identified and surveys conducted among 1,825 hotel customers using simple random sampling techniques. 773 questionnaires were returned with a response rate of around 42.3 percent, 46 questionnaires were deemed unusable because of the large amount of missing data so that 309 analysis units could be used. The results show that customer satisfaction plays a mediating role in the effect of CRM quality and service quality on customer loyalty. The implications are discussed, the limitations of the study are noted and the possible fields for further research are shown.
\end{abstract}

Keywords: CRM quality, service quality, customer satisfaction, customer loyalty

\section{INTRODUCTION}

Nowadays, tourism has been the expectation of substantial foreign exchange earnings for the country. The more increased activities in the tourism services sector by the government, the greater the number of tourists visiting tourist areas scattered in Indonesia. Makassar City and its surroundings have considerable tourism development potential. With the existing natural potential, Makassar City is well-known as the city of tourism, education, center and government of South Sulawesi Province. As a city of educational tourism and the center of government, of course, it will require the provision of adequate urban facilities and infrastructure, because the situation of tourism is growing so that it has an impact on the number of tourists who get in both domestic and foreign tourists. One urban facility that can support tourism potential is the existence of accommodation facilities such as hotels. In general, hotels have a function of handling accommodation for their customers. However, today the functions of the hotel have increasingly varied.

Aside from being lodging, hotels are also used as meeting places, seminars, meetings, wedding parties, and are also used as places for cultural exhibitions. The location of the hotel also affects the function of the hotel, as a transit place, business place, or resort. Hotels or inns with the same class have almost the same service to their customers. Based on the practices of the hotels, there are strategies to distinguish a hotel from another hotel. The way that can be used to show these differences is to build good relationships with customers and offer quality 
services so that customers are satisfied and ultimately loyal to use or use hotel services offered. The management in maintaining survival must be able to meet the needs of consumers in providing the products and services they want, changes to improve better quality in products or services, faster delivery of information, and lower prices compared to competitors of similar businesses. By improving the quality it is expected that in the competition the hospitality service business can survive more than its competitors (Kotler \& Keller, 2012). The phenomenon that occurs shows that the key to increasing customer satisfaction and loyalty lies in the hotel's ability to build effective relationship effectiveness among its business partners. But the challenge faced by hotel management is attracting new customers and maintaining customer loyalty. Hotel management competes by trying to expand each other's market share and get new customers. Therefore the current marketing paradigm for applying the concept of transactional marketing is less relevant because the concept of transactional marketing is oriented towards expanding market share without making efforts to establish long-term relationships with existing customers.

The relationship between the company and the customer ends after a purchase transaction occurs so that customers who are not satisfied easily switch to rival companies that offer high quality goods and services at affordable prices. Understanding customer loyalty is not a new research question, but the relationship between quality and quality management scholars. Customer loyalty is very important for organizations to maintain their current customers. Customer loyalty is one of the performance concepts that shows customer loyalty in buying products or services on a regular basis with a company that is liked, not interested in competing products, and desires to recommend to others. This is because customer loyalty can provide several benefits for the organization such as reducing expenditure costs to attract new customers and increase the profitability of the organization.

Loyalty is a proof that consumers will become customers who have a positive attitude towards the company. Each consumer will have a different loyalty base depending on the perspective of each consumer towards the company and their respective objectivity. Loyalty is not about how many consumers buy a company's products, but how often consumers make purchases within a certain period of time and the repurchase process that has been carried out since the first purchase by the customer (Rowley, 2005). Today, the hotel business faces an increasingly competitive market, and there is a greater need to offer a variety of different products and services to a diverse customer base. Customer relationship management has become a strategic necessity, allowing hotels to tailor their offerings to each customer to suit their individual tastes and to facilitate the processing of customer orders (Meyer \& Schwager, 2007).

The application of the Customer relationship management concept provides several benefits for product providers, namely: (1). Reducing marketing costs, administrative costs, time to get to know consumers, (2). Repurchases, price discounts on superior services, (3). Word of mouth communication (Rahimi \& Kozak, 2017; Al-Qeed et al., 2017). To a large extent, these relationships have been overlooked in quality and relationship marketing research, which has only been concerned with the direct relationship of relationship quality, value and customer engagement with customer loyalty. Extant research has not yet provided a comprehensive account of the role and relevance of relationship quality and value factors and customer engagement, while being assessed for their contribution to customer loyalty (Petzer \& van Tonder, 2019). Empirical evidence shows that the better Customer Relationship Management, customer satisfaction and loyalty will increase significantly (Sari et al., 2009; Yulianti, Sjahruddin, \& Tahir, 2015; Rahimi \& Kozak, 2017; Al-Qeed et al., 2017 ; Sari et al., 2018; Wijaya \& Sahetapy, 2019). Thus, customer loyalty is one of the outputs of marketing and an indicator 
to measure the success of the application of relationship marketing (Kennedy et al. 2001; Thorsten et al., 2002).

The research conducted by Das et al. (2018) explores CRM in several dimensions; there are two dimensions that do not contribute significantly to satisfaction, namely the dimensions of strategy and customer experience. In other parts, the collaboration and vision dimensions are proven to be able to increase customer satisfaction. The results of the study by Lemy et al. (2019) prove that there is a positive relationship between relationship quality and customer loyalty. Long-term customer loyalty will be realized if there is a high emotional bond between the hotel and the customer. The emotional bond will be created if the customer feels satisfied and trusts the hotel, and vice versa the hotel management feels satisfied and trusts the customers. Satisfaction and mutual trust arise after the company and the customer feel that getting the value received matches or exceed the expected value through service quality.

The balance of values obtained by customers from the company and the value obtained by the hotel from customers is the main prerequisite for realizing long-term customer loyalty (Ramli \& Sjahruddin, 2015). Customer satisfaction is positive significantly affects the customer loyalty (Dagger \& O'Brien, 2010; Sheng \& Liu, 2010; Kassim \& Asiah Abdullah, 2010). There has been debate in explaining the effect of satisfaction on loyalty. Providing evidence that satisfaction has a negative effect and an insignificant on customer loyalty (Komunda \& Osarenkhoe, 2012). Functionally, the dimensions of satisfaction have no significant influence on customer loyalty (Abu-ELSamen et al., 2011).

The concept of customer loyalty consists of four dimensions: Purchase intention, word-ofmouth, and complaining behavior (Zeithaml et al., 2000). Customer loyalty to hotel services includes: (1). word-of-mouth that is telling the goodness and superiority of the product of the distributor company where to buy to others, (2) giving recommendations to others to buy goods / services to the distributor company and (3) rejecting the offer of rival company products even though the price is lower and price discount. The success of hotels to maintain customer loyalty is influenced by many factors, including service quality both directly and mediated by the role of increasing customer satisfaction. Satisfaction and dissatisfaction of customers is the impact of the results of customer evaluations of service quality and the value offered by the company. Satisfaction level is a gap of what is the customer's expectation before buying goods / services that are perceived before evaluating the results of the purchase (Zeithalm \& Bitner, 2003). The level of expectation that is smaller or equal to what is felt towards the performance of the product purchased will create a level of satisfaction which in turn affects the level of loyalty, and vice versa (Cronin \& Taylor, 1992).

Customer loyalty is one of the concepts that plays an important role for achieving the goals of a distributor company on an ongoing basis because loyal customers can increase the efficiency and effectiveness of the company, increase profitability and improve hotel competitiveness. On the other hand, loyal customers benefit from reduced risk of uncertainty, performance of products received by customers and reduction in search costs for each product needed by the customer. Conversely, customers who switch because they are disappointed so that they tell their disappointment to others and influence others not to buy, so that in the long run will have a negative impact on the hotel, namely decreased public confidence and will have implications for decreasing demand and income obtained by the hotel. Researchers see service quality as having an important influence on customer satisfaction and customer loyalty. The overall service quality appraisal precedes emotional responses such as customer satisfaction. Further, in the presence of a particular emotion, coping responses such as intent to maintain and enjoy the outcome are possible (customer loyalty). Parasuraman et al. (1988); Makanyeza \& 
Chikazhe (2017) that service quality has a significant and positive effect on customer satisfaction and loyalty. This proves that service quality is a key factor that can build customer satisfaction and loyalty. Customers will feel satisfied and loyal if the quality of service provided by the company is in line with expectations and vice versa the customer will feel disappointed or dissatisfied if the quality of service provided by the company is not in line with his expectations.

The debate was found in a study by Lemy et al. (2019) that the relationship between service quality and customer loyalty is negative. The service literature reports empirical results suggesting that customer satisfaction are an intervening variable that mediates the relationship between overall service quality perception and customer loyalty (Taylor \& Baker, 1994)

Central Bureau of Statistics (BPS) South Sulawesi's released data on the hotel room occupancy rate of star hotels in South Sulawesi in May 2018. In its release, BPS noted, the average TPK or occupancy reached 49.18 percent. On a monthly basis, the TPK in May fell 2.92 points compared to the TPK for 2018 which reached 52.10 percent. The highest decline in TPK was experienced by hotels with a 5-star classification of 14.71 points, while an increase in TPK was only experienced by 1-star hotels, which reached 0.64 points, this condition can also be seen in the decline in foreign tourists who came through the door entering Makassar decreased 7.34 percent compared to 2017. In 2017 the number of foreign tourists coming to Makassar reached 1,281, while in 2017 there were only 1,187 people.

\section{CRM quality}

\section{LITERATURE REVIEW}

The theory of resource-based view (RBV) highlights that control of resources that are valuable $(V)$, rare (R), imperfect imitability and non-substitutability (N) becomes a form of competitive advantage for business (Barney, 1991). Applying RBV, CRM resources can be broadly classified as technology, business and human resources; intentional combination that allows CRM capabilities to be developed. This capability leads to improved company performance (Rapp et al., 2010). The RBV shows that CRM performance improvement is achieved through a combination of technological resources with additional complementary resources (Trainor et al., 2014).

The hotel management in realizing customer loyalty is by optimizing Customer Relationship Management (CRM) quality. CRM quality is one of the marketing strategies that are currently being popularly applied by business managers in Indonesia in retaining existing customers. The way to retain customers that are already owned is by doing a good long-term relationship between the company and existing customers. Some experts argue that there is a relationship between CRM and customer loyalty. CRM is the process of managing all aspects needed by customers to maximize customer loyalty. To achieve a good long-term relationship between the company and the customer, namely by implementing value for customers, especially relying on benefits that exist in CRM. Through the financial benefit approach, social benefits, and structural ties, it is hoped that it will be able to increase customer loyalty by minimizing the possibility of switching customers to other competitors. Financial benefits are related to economic benefits, namely lower prices for a larger purchase. Social benefits are social benefits obtained through a personal approach with customers to build better relationships with customers.

Structural ties are structural bonds where service providers try to help customers by providing information about everything needed, for example through the provision of technology-based 
services (Kotler \& Armstrong, 2013). In a highly competitive environment, hotel businesses have a need to improve the quality of their services in order to retain existing customers while at the same time attempting to attract new segments (Wu \& Lu, 2012). The key factors are the quality and importance of customer relationships. In hotels, CRM applications focus on identifying and retaining the most profitable customers and improving the profitability of less profitable customers (Olsen \& Connolly, 2000; Wang \& Feng, 2012).

According to Gordon (2002) CRM is a series of strategies and processes that create new and mutual value for individual customers build preferences for their organizations and improve business results over a lifetime of association with their customers, CRM can be measured by people, the process, technology and knowledge. One of the roles of Customer Relationship Management is to increase the income of companies / organizations through increasing customer satisfaction. Through service and quality relationships, customers will feel satisfaction and encourage loyalty (Bhakane, 2015). CRM is a holistic process in identifying, attracting, differentiating, and retaining customers by integrating the company's supply chain to create customer value at every step in the value creation process (Tjiptono, 2014). Companies don't stop at customer satisfaction, but more important is how to create loyal customers (customer loyalty).

Zineldin (2006) expended technical-functional quality models into the framework of five quality dimensions (5Qs) which impacting the satisfaction and loyalty of a customer; quality of object (Q1), quality of processes (Q2), quality of infrastructure (Q3), measures of the quality of information exchange (Q4), and quality of atmosphere (Q5). The foregoing shows a link between Customer Relationship Management quality, Customer Satisfaction and Customer Loyalty (Oliver, 1999). This study measures CRM quality using by two dimensions of measurement namely; CRM quality - trust and CRM quality - commitment (Nyadzayo \& Khajehzadeh, 2016).

\section{Services quality}

Service quality cannot be defined if it is not associated with a particular context. Quality is a product characteristic or attribute, this means that to define quality must first be determined. For example reliability is a quality characteristic of a car, the quality of the letter is the clarity of its contents or the length of the letter. Quality is a subjective assessment of the customer; this assessment is determined by the customer's perception of the product (goods and services). This perception can change due to various influences, such as effective advertising, reputation of a particular product, experience, friends, and so on. So it's important to understand: (a) how the product (goods and services) are perceived by the customer, and (b) when the perception changes (Tjiptono, 2014).

Service quality is defined as global judgment or attitude regarding service superiority. The difference between the reality and the expectations of customers for the services they receive or obtain (Parasuraman et al., 1988). Hope is the desire of the customers of the services that may be provided by the company. Service quality can be known by comparing the customers' perceptions of services that they clearly receive or obtain with the services they actually expect and want. If reality is greater than expected, then the service can be said to be of quality, if reality is less than expected, then the service can be said to be not qualified; if reality is the same as hope, service is called satisfying (Fitzsimmons \& Fitzsimmons, 1994). The service success dimension consists of 10 (ten) which are the initial dimensions of servqual (Parasuraman, et al., 1985) (i.e. tangibles, reliability, responsiveness, competence, access, courtesy, communication, credibility, security and understanding / knowing the customer). 
Then Parasuraman et al. (1988) simplify the concept of servqual in five basic dimensions (i.e. tangibles, reliability, responsiveness, assurance and empathy).

\section{Customer satisfaction}

In the service marketing literature, there has been considerable progress in discussing how service quality should be measured. Grönroos (1984) argues that service quality consists of two dimensions: technical quality and functional quality. Technical quality refers to what customers receive as a result of their interactions with a service firm. This aspect can be called the outcome quality dimension. On the other hand, functional quality represents how the service is delivered. In other words, the way service employees interact with customers has an impact on customers' view of the service. This aspect is called the interaction quality dimension. Initially the theory of customer satisfaction conceptualizes simple standards, namely expectations of how goods or services perform their functions. But from the results of research that has been done. Comparative standards used vary in analyzing satisfaction, and even vary throughout the consumption process. Other standards besides expectations used as a comparison are ideal products, competitor products, other product categories, promises from marketers (made through marketing communication) (Woodrulff \& Gardial, 1996).

Satisfaction has an important meaning in the concept of marketing and is usually associated with one slogan satisfying the needs and desires of customers. The use of the term satisfaction in the modern era today tends to be widespread and is related to satisfactory and satisfying words (making it fun). The term customer satisfaction in marketing management itself has a very specific understanding. Customer satisfaction is the customer's response to the fulfillment of needs. This means that the valuation of a form of privilege of an item or service itself provides a level of comfort associated with fulfilling a need including expected needs or meeting needs below customer expectations (Oliver, 1997). The customer satisfaction is an evaluation after-purchase where alternatives are chosen at least equal to exceed customer expectations. While dissatisfaction arises when the results does not meet customer expectations (Engel et al., 1990). Customer Satisfaction the level of a person feels the state resulting from comparing a product's perceived performance (or outcome) in relation to the person's expectation (Kotler, 2000).

Customer satisfaction has become a central concept in marketing theory and practice and is one of the essential goals for business activities. Customer satisfaction contributes to all crucial aspects such as creating customer loyalty. The concept of customer satisfaction used in the study is adopting Caruana (2002) opinion that measurement of customer satisfaction is associated with four dimensions that describe positive responses to behavior after using products offered by the company, namely; expectations of service performance, performance on service performance, non-compliance with service performance, and satisfaction with service performance

\section{Customer loyalty}

The disconfirmation-of-expectation paradigm (Oliver, 1980) argues that customer loyalty (e.g. repurchase intentions, willingness to provide positive word-of-mouth) is a function of customer satisfaction, which again is a function of a cognitive comparison of expectations prior to consumption and actual experience. The concept of business development today is directed at creating and maintaining customer loyalty. The basic reason is loyal customers can increase the company's competitiveness and profitability achieved by the company, on the other hand customers feel guaranteed for the risk of quality of goods / services and procurement of goods and reduce the cost of searching for goods / services needed (Kennedy et al., 2001) . Conversely, customers who are not loyal or turn to rival companies because they are 
disappointed with the quality of products and service quality, describe their disappointment to others or influence people not to buy goods / services in the company so that it will have an impact on the level of profit achieved by the company in the long run. The definition of customer loyalty is always associated with a combination of elements of customer buying attitudes and behavior.

Sheth \& Mittal (2004) said that, in behavior terms, brand loyalty is simply a customer's consistent repurchase of a brand. On a psychological perspective, loyalty is divided into: loyalty to focal brands (loyalty to certain desired brands), actual loyalty in many brands including focal brands, disloyalty but buying focal brands and buying focal brands by chance by loyal / disloyal buyers from other brands (Jacoby \& Chestnut, 1978). The underlying assumption is loyalty requires consistency from three dimensions, namely cognitive, affective and conative customers to focal brands.

Reynolds \& Arnold (2000) formulated the definition of brand loyalty that brand loyalty as a person's tendency to always show the same attitude in the same situation to the previous brands purchased. The definition is seen from the standpoint of attitude, namely customers are said to be loyal if they have a positive attitude towards certain brands all the time. The main disadvantage of measuring loyalty from an attitude perspective is to rely solely on consumer statements rather than based on observed behavior. It is possible for consumers to say they like a particular brand but never buy it. Because the two concepts of customer loyalty above have weaknesses, Sheth \& Mittal (2004) suggest that Thus, customer loyalty is a customer's commitment to a brand, store, or supplier based on favorable attitude and manifested in consistency of patronage. The measurement of customer loyalty is associated with four dimensions that describe positive attitudes and repeat buying behavior, namely: purchase intention, namely the intention of the customer to repurchase the same product or other product in the same company. Customers are said to be loyal if the customer has the intention to repurchase goods / services that are not owned by the same company, Word-of-mouth is the willingness of the customer to tell the good and excellence of the company or product to someone else or give recommendations to others to buy products that, sensitive price, is that the customer is not affected by the offer of a lower price than the competitor or rejects the offer of the competing company product, and Complaining behavior is the willingness of the customer to submit his complaint to the company in polite ways (Zeithaml et al., 1990).

Customer loyalty will be created if the company is able to fulfill its promises at all times. To achieve this goal, the company makes promises that are realistic (making promises), increases the knowledge and motivation of all personnel to be able to carry out promises and all company personnel make a commitment to fulfill the promises that have been submitted to customer. Customer loyalty will be consistent if it is based on nine principles, namely: (1). Partnerships that are based on ethics and high integrity, (2). Added value balance in partnerships between customers and suppliers, (3). Openness between company and customer, (4). Mutual trust between managers, employees, between companies and customers, (5). Help each other actively and concretely, (6). Acting on all elements of customer enthusiasm, for example the quality of timeliness, dependability, ability to cooperate and communication, (7). Proximity to internal and external customers, (8). Anticipate future customer needs and expectations, (9). Continue to build relationships with customers at the after-sales stage (Kennedy et al., 2001). 


\section{Data collection and sample}

\section{RESEARCH METHODOLOGY}

This research is performed by explanatory research with quantitative ties. Respondents for this study included customers who had consumed products and / or used products and services from three hotels (Sahid Jaya Hotel; Aryaduta; The Rinra) in five-star Makassar City (Indonesia) in Makassar City (Indonesia) more than twice. on January to December 2018. The hospitality industry is one of the main supporting sectors of the tourism business and plays an important role in the economy. Three five-star hotels were chosen because they have a higher occupancy rate compared to other five-star hotels. In total, 1,825 questionnaires were distributed and respondents were selected using simple random sampling techniques. There were 773 questionnaires returned, 46 questionnaires were deemed unusable because a large amount of data was lost, maintaining 309 questionnaires that could be used for data analysis. This results in a response rate of around $42.36 \%$. About $65.05 \%$ of respondents were male and most (44.01\%) were in the age group 41-50 years with the intensity of visits to the two times or more.

\section{Measures}

Hypothesis testing in this study using analysis of moment structures ver. 22. Respondents' perceptions of the CRM were measured using trust and commitment using items adopted from Morgan \& Hunt (1994). Service quality was proposed by the five-dimensional measurement scale proposed by Zeithaml et al. (1996). That is, we operationalized service quality as a multidimensional construct with five dimensions including; tangibility, reliability, responsiveness, assurance and empathy. To assess customer satisfaction, we adopted measurement items from Cronin \& Taylor (1992). Customer loyalty towards service providers was assessed using the items from Zeithaml e al. (1996). This approach is considered appropriate because the study is to examine the role of customer satisfaction as a mediating variable explaining the effect of CRM quality and service quality on customer loyalty. The modified 5-point Likert scale $(1=$ strongly disagree; 5 = strongly agree) from the existing literature were used. 


\section{RESULTS}

Table 1. Validity of measurement instruments $(\mathrm{N}=309)$

\begin{tabular}{|c|c|c|c|c|c|c|c|c|c|c|c|c|c|c|c|c|c|c|c|}
\hline $\begin{array}{l}\dot{\hat{n}} \\
\text { ¿े }\end{array}$ & 芦 & छ & $\sum_{\mathcal{U}}$ & 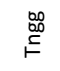 & $\begin{array}{l}\overline{\bar{Q}} \\
\propto\end{array}$ & 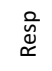 & $\tilde{u}$ & $\stackrel{\varrho}{\tilde{w}}$ & 胥 & 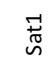 & $\underset{\sim}{\stackrel{N}{N}}$ & 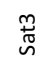 & $\underset{⿱ \mathbb{N}}{\stackrel{+}{ \pm}}$ & 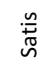 & $\overrightarrow{\widehat{a}}$ & $\widetilde{\widetilde{J}}$ & $\hat{o}$ & 节 & పे \\
\hline Trst & 1 & NA & $\mathrm{NA}$ & $\mathrm{NA}$ & $\mathrm{NA}$ & NA & $\mathrm{NA}$ & $\mathrm{NA}$ & NA & $\mathrm{NA}$ & NA & NA & $\mathrm{NA}$ & $\mathrm{NA}$ & NA & NA & NA & NA & $\mathrm{NA}$ \\
\hline Com & $?$ & 1 & $\mathrm{NA}$ & NA & $\mathrm{NA}$ & NA & $\mathrm{NA}$ & $\mathrm{NA}$ & NA & $\mathrm{NA}$ & NA & NA & $\mathrm{NA}$ & NA & NA & NA & NA & NA & NA \\
\hline CRM & $\stackrel{\infty}{\infty}$ & ळ. & 1 & $\mathrm{NA}$ & $\mathrm{NA}$ & $\mathrm{NA}$ & $\mathrm{NA}$ & $\mathrm{NA}$ & NA & $\mathrm{NA}$ & NA & NA & $\mathrm{NA}$ & $\mathrm{NA}$ & $\mathrm{NA}$ & NA & $\mathrm{NA}$ & NA & NA \\
\hline Tngg & NA & $\mathrm{NA}$ & $\mathrm{NA}$ & 1 & $\mathrm{NA}$ & $\mathrm{NA}$ & $\mathrm{NA}$ & $\mathrm{NA}$ & NA & $\mathrm{NA}$ & $\mathrm{NA}$ & $\mathrm{NA}$ & $\mathrm{NA}$ & $\mathrm{NA}$ & $\mathrm{NA}$ & NA & $\mathrm{NA}$ & NA & $\mathrm{NA}$ \\
\hline Reli & NA & $\mathrm{NA}$ & $\mathrm{NA}$ & $\vec{\sigma}$ & 1 & NA & $\mathrm{NA}$ & NA & NA & $\mathrm{NA}$ & $\mathrm{NA}$ & $\mathrm{NA}$ & $\mathrm{NA}$ & $\mathrm{NA}$ & NA & $\mathrm{NA}$ & $\mathrm{NA}$ & NA & $\mathrm{NA}$ \\
\hline Resp & NA & NA & NA & ต̣ & ถุ & 1 & $\mathrm{NA}$ & NA & NA & $\mathrm{NA}$ & NA & $\mathrm{NA}$ & $\mathrm{NA}$ & $\mathrm{NA}$ & NA & $\mathrm{NA}$ & NA & NA & $\mathrm{NA}$ \\
\hline Ass & NA & $\mathrm{NA}$ & NA & ๑ே & $\tilde{\sigma}$ & क़े & 1 & NA & NA & $\mathrm{NA}$ & $\mathrm{NA}$ & $\mathrm{NA}$ & $\mathrm{NA}$ & $\mathrm{NA}$ & NA & NA & NA & NA & NA \\
\hline Emp & NA & NA & $\mathrm{NA}$ & $\stackrel{\infty}{\infty}$ & ต̣ & ณn & ต̣ & 1 & NA & $\mathrm{NA}$ & NA & $\mathrm{NA}$ & $\mathrm{NA}$ & $\mathrm{NA}$ & NA & NA & NA & NA & $\mathrm{NA}$ \\
\hline Serl & NA & NA & $\mathrm{NA}$ & ๓n & के & $\stackrel{\infty}{\sigma}$ & के & ọ & 1 & $\mathrm{NA}$ & $\mathrm{NA}$ & $\mathrm{NA}$ & $\mathrm{NA}$ & $\mathrm{NA}$ & $\mathrm{NA}$ & $\mathrm{NA}$ & NA & NA & $\mathrm{NA}$ \\
\hline Sat1 & $\mathrm{NA}$ & NA & $\mathrm{NA}$ & $\mathrm{NA}$ & $\mathrm{NA}$ & $\mathrm{NA}$ & $\mathrm{NA}$ & $\mathrm{NA}$ & NA & 1 & NA & NA & $\mathrm{NA}$ & NA & NA & $\mathrm{NA}$ & NA & NA & NA \\
\hline Sat2 & $\mathrm{NA}$ & $\mathrm{NA}$ & NA & $\mathrm{NA}$ & $\mathrm{NA}$ & $\mathrm{NA}$ & $\mathrm{NA}$ & $\mathrm{NA}$ & $\mathrm{NA}$ & $\infty$ & 1 & $\mathrm{NA}$ & $\mathrm{NA}$ & $\mathrm{NA}$ & $\mathrm{NA}$ & NA & $\mathrm{NA}$ & $\mathrm{NA}$ & NA \\
\hline Sat3 & $\mathrm{NA}$ & $\mathrm{NA}$ & $\mathrm{NA}$ & $\mathrm{NA}$ & $\mathrm{NA}$ & $\mathrm{NA}$ & $\mathrm{NA}$ & NA & $\mathrm{NA}$ & $\stackrel{t}{t}$ & $\stackrel{\nabla}{r}$ & 1 & $\mathrm{NA}$ & $\mathrm{NA}$ & $\mathrm{NA}$ & NA & $\mathrm{NA}$ & $\mathrm{NA}$ & NA \\
\hline Sat4 & $\mathrm{NA}$ & $\mathrm{NA}$ & NA & NA & $\mathrm{NA}$ & $\mathrm{NA}$ & $\mathrm{NA}$ & NA & NA & $\stackrel{n}{?}$ & 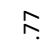 & 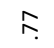 & 1 & NA & NA & NA & $\mathrm{NA}$ & NA & NA \\
\hline Satis & $\mathrm{NA}$ & $\mathrm{NA}$ & $\mathrm{NA}$ & $\mathrm{NA}$ & $\mathrm{NA}$ & $\mathrm{NA}$ & $\mathrm{NA}$ & $\mathrm{NA}$ & NA & क़ & n़ & ळ & ๑ุ & 1 & NA & NA & $\mathrm{NA}$ & NA & $\mathrm{NA}$ \\
\hline Loy1 & $\mathrm{NA}$ & $\mathrm{NA}$ & NA & $\mathrm{NA}$ & $\mathrm{NA}$ & $\mathrm{NA}$ & $\mathrm{NA}$ & $\mathrm{NA}$ & NA & $\mathrm{NA}$ & NA & $\mathrm{NA}$ & $\mathrm{NA}$ & NA & 1 & $\mathrm{NA}$ & NA & $\mathrm{NA}$ & $\mathrm{NA}$ \\
\hline Loy2 & $\mathrm{NA}$ & $\mathrm{NA}$ & NA & $\mathrm{NA}$ & $\mathrm{NA}$ & $\mathrm{NA}$ & $\mathrm{NA}$ & NA & NA & $\mathrm{NA}$ & $\mathrm{NA}$ & $\mathrm{NA}$ & $\mathrm{NA}$ & $\mathrm{NA}$ & $\Phi_{\infty}$ & 1 & $\mathrm{NA}$ & $\mathrm{NA}$ & NA \\
\hline Loy3 & $\mathrm{NA}$ & $\mathrm{NA}$ & $\mathrm{NA}$ & NA & $\mathrm{NA}$ & $\mathrm{NA}$ & $\mathrm{NA}$ & $\mathrm{NA}$ & NA & $\mathrm{NA}$ & NA & $\mathrm{NA}$ & $\mathrm{NA}$ & $\mathrm{NA}$ & r. & $\widetilde{\infty}$ & 1 & $\mathrm{NA}$ & $\mathrm{NA}$ \\
\hline Loy4 & $\mathrm{NA}$ & $\mathrm{NA}$ & $\mathrm{NA}$ & $\mathrm{NA}$ & $\mathrm{NA}$ & $\mathrm{NA}$ & $\mathrm{NA}$ & $\mathrm{NA}$ & $\mathrm{NA}$ & $\mathrm{NA}$ & NA & $\mathrm{NA}$ & $\mathrm{NA}$ & NA & 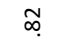 & $\infty$ & $\stackrel{\infty}{\stackrel{1}{r}}$ & 1 & $\mathrm{NA}$ \\
\hline Loy & NA & NA & $\mathrm{NA}$ & NA & $\mathrm{NA}$ & $\mathrm{NA}$ & $\mathrm{NA}$ & NA & NA & NA & NA & NA & $\mathrm{NA}$ & NA & $\stackrel{n}{a}$ & ọ & क̆ & สุ & 1 \\
\hline
\end{tabular}

Correlation (Validity) is significant at the 0.01 level (2-tailed) $=<0,05$

When steps are adapted from existing literature, confirmatory factor analysis (CFA) is carried out in AMOS to assess the nature of dimensions in our context. Using maximum likelihood (ML) estimation, we run the CFA model with all constructs (i.e. CRM quality indicated by two dimensions; service quality with five dimensions and for customer satisfaction and customer loyalty, each measured by four dimensions) the overall measurement model shows acceptable suitability (Chi-square $=65,989$, CMIN $/ \mathrm{df}=1.26$, probability $=.09$, RMSEA $=.03, \mathrm{GFI}=.96$, $\mathrm{AGFI}=.91, \mathrm{df}=52, \mathrm{CFI}=.99, \mathrm{TLI}=.99)$, showing adequate convergence or internal consistency (Hair et al., 2006; Sjahruddin \& Sudiro, 2013). Factor weight values have estimates of mean variance $(\mathrm{AVE})=>.70$ and the value of built-up reliability $(\mathrm{CR})$ above 0.70 , indicating conformity to convergent validity (Fornell \& Larcker, 1981). The overall value of factor loading is significant $=>.80$. Also, reliability analysis showed that the construct had Cronbach's alpha $=>.80$. 
Table 2. Factor loadings and Cronbach's alpha

\begin{tabular}{ccccc}
\hline & Constructs & & Factor loadings & Cronbach's alpha \\
\hline Com & $<---$ & CRM quality & 0.86 & .84 \\
Trst & $<---$ & CRM quality & 0.82 & \\
Reli & $<---$ & Serv & 0.96 & .98 \\
Tngg & $<---$ & Serv & 0.94 & \\
Resp & $<---$ & Serv & 0.98 & \\
Ass & $<---$ & Serv & 0.96 & \\
Emp & $<---$ & Serv & 0.97 & .93 \\
Sat3 & $<---$ & Sat & 0.82 & \\
Sat4 & $<---$ & Sat & 0.86 & \\
Sat2 & $<---$ & Sat & 0.92 & \\
Sat1 & $<---$ & Sat & 0.93 & .94 \\
Loy3 & $<---$ & Loy & 0.86 & \\
Loy4 & $<---$ & Loy & 0.89 & \\
Loy2 & $<---$ & Loy & 0.93 & \\
Loy1 & $<---$ & Loy & 0.91 & \\
\hline
\end{tabular}

The results of this study indicate that there are several causality between variables (hypotheses) are supported in this study, as shown in the following table:

Table 3. Results for the direct and indirect effects

(a) Direct effects

\begin{tabular}{|lll|rrrr|}
\hline \multicolumn{2}{|c|}{ Direct relationship tested } & & Estimate & S.E. & C.R. & $\begin{array}{c}\text { P- } \\
\text { value }\end{array}$ \\
\hline CRM quality & $\rightarrow$ & Sat & 0.52 & 0.24 & 2.18 & 0.03 \\
Serv & $\rightarrow$ & Sat & 0.81 & 0.25 & 3.20 & 0.00 \\
CRM & $\rightarrow$ & Loy & 0.04 & 0.02 & 1.87 & 0.06 \\
Serv & $\rightarrow$ & Loy & 0.35 & 0.07 & 4.81 & $* * *$ \\
Sat & $\rightarrow$ & Loy & 1.71 & 0.11 & 15.49 & $* * *$ \\
\hline
\end{tabular}

(b) Indirect effects (Sobel test)

\begin{tabular}{|c|c|c|c|c|c|c|}
\hline \multicolumn{4}{|c|}{ Indirect relationship tested } & S.E. & C.R. & $\begin{array}{c}\text { P- } \\
\text { value }\end{array}$ \\
\hline CRM quality & Sat & $\rightarrow$ & Loy & 0.41 & 2.16 & 0.03 \\
\hline Serv & Sat & $\rightarrow$ & Loy & 0.44 & 3.14 & 0.00 \\
\hline
\end{tabular}

\section{H1a: CRM quality on customer satisfaction}

The effect of CRM quality to customer satisfaction can be evidenced by the value of the standardized regression weight estimate of 0.334 with positive direction. The coefficient is positive, meaning that CRM quality at high level results in an increase in customer satisfaction. Besides that, it can also be proven by the value of the critical ratio $=2.179>1.96$ and the $p$ value $=0.029<0.05$. The results of testing the H1a prove that CRM quality has a significant positive effect on customer satisfaction of five-star hotels in Makassar City. 
The statement can be interpreted that CRM quality at a high level is proven to be able to provide a real (meaningful) influence on the creation of satisfaction felt by customers in enjoying hotel products and services. CRM quality is very important in ensuring hotel survival and maintaining added value and hotel relationships with key consumers. CRM quality is the reason for management to produce and deliver high-quality core products and support services in a more systematic way. Good relationships with customers have a positive impact so hotel management has the best opportunity to maintain transactions with customers and concentrate on efforts to serve them in ways that are better than competitors. This condition is caused because hotels have created CRM quality through the delivery and approach of the relationship between hotels and customers, price compatibility with the services provided. Increasing customer depends on factors, namely customer satisfaction, efforts to provide satisfaction to customers is to create good relationships with customers based on so that if the relationship with customers can run well, the hotel can achieve its goal to increase the number of customers.

Customer Relationship Management is the process of building and maintaining long-term relationships that will satisfy customers through providing valuable and satisfying services. (Kotler \& Armstrong, 2013). The results of this study are relevant with the findings of previous researchers that CRM is a strategy to improve customer relationship interactions so as to produce mutually beneficial relationships between company management and customers. CRM has a significant effect on customer satisfaction in industrial organizations in India. Effective CRM leads to customer satisfaction and if satisfied customers will push in a positive direction (Bhakane, 2015). The better the application of CRM, the customer satisfaction will increase significantly (Parasuraman et al. 1988; Sari, 2009; Nyadzayo \& Khajehzadeh, 2016; Yulianti, Sjahruddin, \& Tahir, 2015; Rahimi \& Kozak, 2017; Al-Qeed et al., 2017; Makanyeza \& Chikazhe, 2017; Sari et al., 2018;; Das et al., 2018; Lemy et al., 2019; Wijaya \& Sahetapy, 2019).

\section{H1b: CRM quality on customer loyalty}

The effect of CRM quality to customer loyalty can be proved by the value of standardized regression weight estimate of 0.027 with a positive direction. The influence coefficient is positive, meaning that high CRM quality, resulting in an increase in customer loyalty to be more intense in using hotel products and services, but because of the low standardized regression weight estimate, the increase is not able to contribute meaningfully to customer loyalty. It can also be proved by the value of the critical ratio $=1.871<1.96$ and the $p$-value of $0.061>0.05$. The results of testing the H1b prove that CRM quality has a positive and insignificant effect on customer loyalty of five-star hotels in Makassar City.

CRM quality that is applied to five-star hotels in Makassar City must always be improved because the hotel business is not only oriented to the creation of satisfaction, but more to the creation of customer loyalty. This is because customer loyalty can provide several benefits for hotel management, such as reducing costs to attract new customers and increasing the profitability of hotels.

Loyalty is a proof that consumers will become customers who have a positive attitude towards the hotel. Each consumer will have a different loyalty base depending on the perspective of each consumer towards the company and their respective objectivity. Loyalty is not about how many consumers buy a company's products, but how often consumers make purchases within a certain period of time and the repurchase process that has been carried out since the first purchase made by the customer (Rowley, 2005). This study supports rejecting the findings of previous researchers that CRM quality has proven to be able to make a positive contribution to management and has an impact on the customer's desire to re-use hotel products and services 
(Parasuraman et al. 1988; Sari, 2019; Nyadzayo \& Khajehzadeh, 2016; Yulianti, Sjahruddin , \& Tahir, 2017; Rahimi \& Kozak, 2017; Al-Qeed et al., 2017; Makanyeza \& Chikazhe, 2017; Sari et al., 2018; Wijaya \& Sahetapy, 2019; Wijaya, 2019; Das et al., 2018 ).

\section{H2a: Service quality on customer satisfaction}

The effect of service quality on customer satisfaction can be proven by the standardized regression weight estimate of 0.529 in a positive direction. The influence coefficient is positive, meaning that service quality is high, resulting in an increase in customer satisfaction. This can also be proven by the value of the critical ratio $=3.201>1.96$ and $p$-value $=0.001<0.05$. The results of $\mathrm{H} 2 \mathrm{a}$ prove that service quality has a significant positive effect on customer satisfaction of five-star hotels in Makassar City.

The statement can be interpreted that high service quality is proven to increase customer satisfaction to always use hotel products and services. Some scholars state that in the service industry, the emphasis is on the importance of service quality and the relationship of service quality and customer satisfaction (Cronin \& Taylor, 1992). The relationship of service quality and customer satisfaction is explained by Oliver (1993) as a relationship of service quality which is an antecedent for customer satisfaction, regardless of whether service quality and customer satisfaction are measured at specific experiences over time.

Good and modern hotel facilities and fast response to customer needs will result in customers feeling satisfied. In addition, security guarantees make customers feel that the hotel is the right choice. Customers who feel satisfied if the performance of the quality of service provided is in accordance with expectations and vice versa the customer will feel dissatisfied if it is not in accordance with the expectations given. Service quality can be known by comparing the customers' perceptions of services that they clearly receive or obtain with the services they actually expect and want. If reality is greater than expected, then service can be said to be of high quality, if reality is less than expected, then service can be said to be inadequate; if reality is the same as hope, service is called satisfying (Fitzsimmons \& Fitzsimmons 1994). This means that the assessment of a product or service provides a level of comfort associated with fulfilling a need including expected needs (Oliver, 1997). This study supports the findings of previous researchers that service quality is an antecedent of customer satisfaction (Parasuraman et al., 1988; Makanyeza \& Chikazhe, 2017).

\section{H2b: Service quality on customer loyalty}

The effect of service quality on customer loyalty can be proven by the standardized regression weight estimate value of 0.638 with a positive direction. The influence coefficient is positive, meaning that service quality is high, resulting in an increase in customer loyalty. This can also be proven by the value of the critical ratio $=4.814>1.96$ and $p$-value $=0,000<0.05$. The results of testing H2b prove that service quality has a significant positive effect on customer loyalty of five-star hotels in Makassar City. The higher quality of service provided by hotel management to customers results in customers becoming loyal.

The success of the hotel to build and maintain customer loyalty is strongly influenced by the quality of service, good quality of service, professionals in conducting customer education with the aim of raising awareness, confidence and action for reusing hotel products and services This means that after customers use hotel products and services will feel the importance of lodging in supporting daily activities, arises the desire to reuse products and services or repeat purchases, tell the benefits of service to others, reject offers of competing products or services even though with low rates and customers are not awkward to submit complaints to the hotel management. This study supports the findings of previous researchers that service quality is 
an antecedent of customer satisfaction (Parasuraman et al., 1988; Makanyeza \& Chikazhe, 2017). Refusing the findings of previous researchers that the relationship between service quality and customer loyalty is negative (Lemy et al., 2019).

\section{H3: Effect of customer satisfaction on customer loyalty}

The effect of customer satisfaction on customer loyalty can be proven by the value of standardized regression weight estimate of 0.857 in a positive direction. The influence coefficient is positive, meaning that the high level of satisfaction that the customer feels is driving the customer to further increase their loyalty. This can also be proven by the value of the critical ratio $=15,488>1,96$ and $\mathrm{p}$-value $=0,000<0,05$. The results of $\mathrm{H} 3$ prove that the satisfaction felt by customers in using hotel products and services has a significant positive effect on customer loyalty of five-star hotels in Makassar City. Customer loyalty will be created if the company is able to fulfill its promises at all times. To achieve these objectives, the company makes promises that are realistic (making promises), increases the knowledge and motivation of all personnel to be able to carry out promises and all company personnel make a commitment to fulfill the promises that have been submitted to the customer (Kennedy et al., 2001). Long-term customer loyalty will be realized if there is a high emotional bond between the hotel and the customer. The emotional bond will be created if the customer feels satisfied and trusts the hotel, and vice versa the hotel management feels satisfied and trusts the customers. Feelings of satisfaction and mutual trust occur after the hotel and the customer feel that getting the value received matches or exceed the expected value through the quality of service. The balance of value obtained by customers from the company and the value obtained by the hotel from customers is the main prerequisite for realizing long-term customer loyalty. This study supports the findings of previous researchers that perceived satisfaction becomes a benchmark for the creation of customer satisfaction (Ramli \& Sjahruddin, 2015). Customer satisfaction is positive and significantly affects the customer loyalty (Dagger \& O'Brien, 2010; Sheng \& Liu, 2010; Kassim \& Asiah, 2010; Nyadzayo \& Khajehzadeh, 2016). There has been debate in explaining the effect of satisfaction on loyalty. Providing evidence that satisfaction has a negative effect and an insignificant on customer loyalty (Komunda \& Osarenkhoe, 2012). Functionally, the dimensions of satisfaction have no significant influence on customer loyalty (Abu-ELSamen et al., 2011)

\section{H4a: CRM quality on customer loyalty: As a mediating role of customers satisfaction}

The use of Sobel test shows that the value of critical ratio $=2.156>1.96$ and $p$-value $=0.031$ $<0.05$. Based on these results, it can be explained that the effect of CRM quality through customer's satisfaction on customer satisfaction proved significant. Testing the mediation effect using an examination approach provides evidence that customer satisfaction acts as a complete mediation in analyzing the effect of CRM quality on customer loyalty. This study provides evidence that without the support of high customer satisfaction creation, the quality CRM is used management is unable to increase hotel customer loyalty. The results of this study are relevant to previous research findings that CRM has a significant effect on customer retention through customer satisfaction (Das et al., 2018)

\section{H4b: Service quality on customer loyalty: As a mediating role of customers satisfaction}

The use of Sobel test shows that the value of the critical ratio $=3.135>1.96$ and $p$-value $=0.001$ $<0.05$. Based on these results, it can be explained that the effect of service quality through customer's satisfaction on customer loyalty is significant. Testing of mediation effects using the audit approach provides evidence that customer satisfaction is declared not proven (not) as a mediating variable in analyzing the effect of service quality on customer loyalty. This means that without being supported by customer satisfaction, the quality of services provided by hotels has been able to increase the desire of customers to come back to use hotel products and 
services, even recommend to others. This research is in accordance with the results of previous researchers' research that service quality has a significant effect on consumer loyalty which is mediated by customer satisfaction (Osman \& Sentosa, 2013; Kaura et al., 2015).

\section{CONCLUSIONS AND RECOMMENDATIONS}

CRM quality at a high level is proven to be able to provide a real (meaningful) influence on the creation of satisfaction that customers feel in enjoying hotel products and services. CRM quality is very important in ensuring hotel survival and maintaining added value and hotel relationships with customers. CRM quality that is implemented by five-star hotels in Makassar City must always be improved because the hotel business is not only oriented to the creation of satisfaction, but more to the creation of customer loyalty. High service quality is proven to increase customer satisfaction to always use hotel products and services.

Good and modern hotel facilities and fast response to customer needs will result in customers feeling satisfied. In addition, security guarantees make customers feel that the hotel is the right choice. The higher quality of service provided by hotel management to customers results in customers becoming loyal. The success of the hotel to build and maintain customer loyalty is strongly influenced by the quality of service, good quality of service, professionals in conducting customer education with the aim of raising awareness, confidence and action for reusing hotel products and services Customer loyalty will be created if the company is able to fulfill its promises at all times.

To achieve this goal, the hotels company makes promises that are realistic (making promises), increases the knowledge and motivation of all personnel to be able to carry out promises and all company personnel make a commitment to fulfill the promises that have been submitted to customers. Long-term customer loyalty will be realized if there is a high emotional bond between the hotel and the customer. The emotional bond will be created if the customer feels satisfied and trusts the hotel, and vice versa the hotel management feels satisfied and trusts the customers. Without being supported by the creation of high customer satisfaction, CRM quality used by management is not able to increase hotel customer loyalty.

Support from customer satisfaction has resulted in the quality of services provided by the hotel has been able to increase the desire of customers to come back to use hotel products and services, even recommend to others. This research is not good enough to substitute service quality. Limitations of research exist as a result of trade-offs in research design decisions. Although our research model was developed based on theoretical reasons, its generalizability was limited to the hospitality industry in Indonesia. This is consistent with the service marketing literature that encourages the development of marketing knowledge bodies in the single service industry. The potential area of research in the future is to test our models in other service industries, as well as in developing and developed countries to test their generalizability. However, given the fact that our research is exploratory and for the efficiency of data collection, we believe that we have used adequate definitions in building models. Investigating the multi-dimensional aspects of relationship marketing in relation to other constructs in our model will be a useful field of relational marketing research in the future. 
Mokhtar, S., Mus, A. M., \& Sjahruddin, H. (2019). An examination of the relationships between customer relationship management quality, service quality, customer satisfaction and customer loyalty: The case of five star hotels. Advances in Social Sciences Research Journal, 6(2) 524-540.

\section{References}

Abu-ELSamen, AA, Akroush, MN, Al-Khawaldeh, FM, \& Al-Shibly, MS (2011). Towards an integrated model of customer service skills and customer loyalty: The mediating role of customer satisfaction. International Journal of Commerce and Management, 21 (4), 349-380. https://doi.org/10.1108/10569211111189365

Al-Qeed, MA, ALsadi, BY, \& Al-Azzam, ZF (2017). The Impact of Customer Relationship Management on Achieving Service Quality of Banking Sector of Jordan. International Journal of Business and Management, 12 (3), 180.

Barney, J. (1991). Firm resources and sustained competitive advantage. Journal of management, 17 (1), $99-120$. https://doi.org/10.1177/014920639101700108

Bhakane, B. (2015). Effect of customer relationship management on customer satisfaction and loyalty.

Caruana, A. (2002). Service loyalty: The effects of service quality and the mediating role of customer satisfaction. European journal of marketing, 36 (7/8), 811-828. https://doi.org/10.1108/03090560210430818

Central Bureau of Statistics. (2018) Room Occupancy Rates in Makassar City, South Sulawesi Province Cronin Jr, JJ, \& Taylor, SA (1992). Measuring service quality: a reexamination and extension. The journal of marketing, 55-68. https://doi.org/10.2307/1252296

Dagger, TS, \& O'Brien, TK (2010). Does experience matter? Differences in relationship benefits, satisfaction, trust, commitment and loyalty for novice and experienced service users. European Journal of Marketing, 44 (9/10), 1528-1552. https://doi.org/10.1108/03090561011062952

Engel, JF, Blackwell, RD \& Miniard, PW (1990), Consumer Behavior, Dryden, Chicago, IL

Fitzsimmons, JA, \& Fitzsimmons, MJ (1994). Service management for competitive advantage. New York, NY: McGraw-Hill.

Gordon, I. (2002). Best practices: Customer relationship management. Ivey Business Journal, 67 (2), 1-5.

Grönroos, C. (1984). A service quality model and its marketing implications. European Journal of marketing, 18(4), 36-44. https://doi.org/10.1108/EUM0000000004784

Hair, JF (2006). Multivariate Data Analysis. Edition 5. Jakarta: Gramedia Main Library

Jacoby, J., \& Chestnut, RW (1978). Brand loyalty: Measurement and management. John Wiley \& Sons Incorporated.

Kassim, N., \& Asiah Abdullah, N. (2010). The effect of perceived service quality on customer satisfaction, trust, and loyalty in e-commerce settings: A cross cultural analysis. Asia Pacific Journal of Marketing and Logistics, 22 (3), 351-371. https://doi.org/10.1108/13555851011062269

Kaura, V., Durga Prasad, CS, \& Sharma, S. (2015). Service quality, convenience services, price and fairness, customer loyalty, and the mediating role of customer satisfaction. International Journal of Bank Marketing, 33 (4), 404-422. https://doi.org/10.1108/IJBM-04-2014-0048

Kennedy, MS, Ferrell, LK, \& LeClair, DT (2001). Consumers' trust of salesperson and manufacturer: an empirical study. Journal of Business Research, 51 (1), 73-86.

Komunda, M., \& Osarenkhoe, A. (2012). Remedy or cure for service failure? Effects of service recovery on customer satisfaction and loyalty. Business Process Management Journal, 18 (1), 82-103.

https://doi.org/10.1108/14637151211215028

Kotler, Philip \& Armstrong, Gary. (2013). Principles of Marketing, 12th Edition. Erlangga Publisher.

Kotler, Philip \& Kevin Lane Keller. (2012). Marketing Management 13. New Jersey: Pearson Prentice Hall, Inc.

Kotler, Philip (2000). Principles - Principles of Marketing Management, Jakarta: Prenhalindo

Lemy, D., Goh, E., \& Ferry, J. (2019). Moving out of the silo: How service quality innovations can develop customer loyalty in Indonesia's hotels. Journal of Vacation Marketing. https://doi.org/10.1177/1356766718819658

Makanyeza, C., \& Chikazhe, L. (2017). Mediators of relationship between service quality and customer loyalty: Evidence from the banking sector in Zimbabwe. International Journal of Bank Marketing, 35 (3), 540-556. https://doi.org/10.1108/IJBM-11-2016-0164

Morgan, RM, \& Hunt, SD (1994). The commitment-trust theory of relationship marketing. The journal of marketing, 20-38. https://doi.org/10.2307 / 1252308

Nyadzayo, MW, \& Khajehzadeh, S. (2016). The antecedents of customer loyalty: A moderated mediation model of customer relationship management quality and brand image. Journal of Retailing and Consumer Services, 30, 262270. https://doi.org/10.1016/i.jretconser.2016.02.002 
Oliver, R. L. (1980). A cognitive model of the antecedents and consequences of satisfaction decisions. Journal of marketing research, 460-469. https://doi.org/10.2307/3150499

Oliver, RL (1993). Cognitive, affective, and bases of satisfaction response attributes. Journal of consumer research, 20 (3), 418-430. https://doi.org/10.1086/209358

Oliver, RL (1997). Satisfaction: A Behavioral Perspective on the Consumer. New York: McGraw Hill

Olsen, MD, \& Connolly, DJ (2000). Experience-based travel: How technology is changing the hospitality industry. Cornell Hotel and Restaurant Administration Quarterly, 41 (1), 30-40. https://doi.org/10.1177/001088040004100121

Osman, Z., \& Sentosa, I. (2013). The mediating effect of customer satisfaction on service quality and customer loyalty relationships in Malaysian rural tourism.

Parasuraman, A., Zeithaml, VA, \& Berry, LL (1985). A conceptual model of service quality and its implications for future research. the Journal of Marketing, 41-50. https://doi.org/10.2307/1251430

Parasuraman, A., Zeithaml, VA, \& Berry, LL (1988). Servqual: A multiple-item scale for measuring consumer perceptions. Journal of retailing, 64 (1), 12.

Petzer, DJ, \& van Tonder, E. (2019). Loyalty intentions and selected relationship quality constructs: The mediating effect of customer engagement. International Journal of Quality \& Reliability Management. https://doi.org/10.1108/IJQRM-06-2018-0146

Rahimi, R., \& Kozak, M. (2017). Impact of customer relationship management on customer satisfaction: The case of a budget hotel chain. Journal of Travel \& Tourism Marketing, 34 (1), 40-51. https://doi.org/10.1080/10548408.2015.1130108

Ramli, AH, \& Sjahruddin, H. (2015). Building patient loyalty in healthcare services. International Review of Management and Business Research, 4 (2), 391.

Rapp, A., Trainor, KJ, \& Agnihotri, R. (2010). Performance implications of customer-linking capabilities: Examining the complementary role of customer orientation and CRM technology. Journal of Business research, 63 (11), 12291236. https://doi.org/10.1016/i.jbusres.2009.11.002

Reynolds, K. E., \& Arnold, M. J. (2000). Customer loyalty to the salesperson and the store: examining relationship customers in an upscale retail context. Journal of personal selling \& sales management, 20(2), 89-98. https://doi/abs/10.1080/08853134.2000.10754228

Rowley, J. (2005). The four Cs of customer loyalty. Marketing intelligence \& planning, 23 (6), 574-581. https://doi.org/10.1108/02634500510624138

Sari, HK (2009). Effectiveness of Loyalty Programs in Customer Relationship Management on Customer Satisfaction and Loyalty (Study of the Activity of the Retention Division in the Im3 @ School Community Loyalty Program at PT Indosat Tbk. Malang Branch Office).

Sari, NP, Daryanto, HK, \& Saptono, IT (2018). Effect of Customer Relationship Management on PT Bank BNI Customer Satisfaction and Loyalty. Journal of Business and Management Applications (JABM), 4 (1), 129.

Sheng, T., \& Liu, C. (2010). An empirical study of the effect of e-service quality on online customer satisfaction and loyalty. Nankai international business review, 1 (3), 273-283. https://doi.org/10.1108/20408741011069205

Sheth, JN, Mittal, B., Newman, BI, \& Sheth, JN (2004). Customer behavior: A managerial perspective.

Taylor, S. A., \& Baker, T. L. (1994). An assessment of the relationship between service quality and customer satisfaction. Journal of retailing, 70(2), 163-178.

Tjiptono, Fandy. (2014), Marketing Services - Principles, Applications, and Research, Andi Offset, Yogyakarta.

Trainor, KJ, Andzulis, JM, Rapp, A., \& Agnihotri, R. (2014). Social media usage and customer relationship performance media: A capabilities-based examination of social CRM. Journal of Business Research, 67 (6), 1201 1208. https://doi.org/10.1016/i.jbusres.2013.05.002

Wang, Y., \& Feng, H. (2012). Customer relationship management capabilities: Measurement, antecedents and consequences. Management Decision, 50 (1), 115-129. https://doi.org/10.1108/00251741211194903

Wijaya, BS \& Sahetapy. WS (2019). Analysis of the effect of customer relationship management on customer satisfaction and customer loyalty (Study at Kafe Damgo Makassar). Agora, 7 (1).

Woodruff, RB, \& Gardial, S. (1996). Know your customer: New approaches to understanding customer value and satisfaction. Wiley. 
Mokhtar, S., Mus, A. M., \& Sjahruddin, H. (2019). An examination of the relationships between customer relationship management quality, service quality, customer satisfaction and customer loyalty: The case of five star hotels. Advances in Social Sciences Research Journal, 6(2) 524-540.

Wu, SI, \& Lu, CL (2012). The relationship between CRM, RM, and business performance: A study of the hotel industry in Taiwan. International Journal of Hospitality Management, 31 (1), 276-285.

https://doi.org/10.1016/j.ijhm.2011.06.012

Yulianti, L., Sjahruddin, H., \& Tahir, B. (2015). Implementation of Customer Relationship Management (CRM) on Customer Satisfaction and Loyalty of Samsung Brand Android Smartphone Users. Journal of Organization and Management. September, 1-15

Zeithaml, VA (2000). Service quality, profitability, and the economic worth of customers: what we know and what we need to learn. Journal of the academy of marketing science, 28 (1), 67-85.

https://doi.org/10.1177\%2F0092070300281007

Zeithaml, VA, \& Bitner, MJ (2003). Services Marketing: Integrating Customer Focus Across the Firm. New York: McGraw-Hill

Zeithaml, VA, Berry, LL, \& Parasuraman, A. (1996). The behavioral consequences of service quality. the Journal of Marketing, 31-46. https://doi.org/10.2307/1251929

Zeithaml, VA, Parasuraman, A., Berry, LL, \& Berry, LL (1990). Delivering quality service: Balancing customer perceptions and expectations. Simon and Schuster.

Zineldin, M. (2006). The quality of health care and patient satisfaction: an exploratory investigation of the 5Qs model at some Egyptian and Jordanian medical clinics. International journal of health care quality assurance, 19 (1), 60-92. https://doi.org/10.1108/09526860610642609 